\section{Influence of Irrigation Method and Scheduling on Patterns of Soil and Tree Water Status and Its Relation to Yield and Fruit Quality in Peach}

\author{
David R. Bryla, ${ }^{1}$ Elizabeth Dickson, ${ }^{2}$ and Robert Shenk \\ U.S. Department of Agriculture, Agricultural Research Service, Water \\ Management Research Laboratory, 9611 South Riverbend Avenue, Parlier, \\ CA 93648
}

\section{R. Scott Johnson and Carlos H. Crisosto \\ University of California, Department of Plant Sciences at Kearney Agricultural Center, 9240 South Riverbend Avenue, Parlier, CA 93648}

\section{Thomas J. Trout}

U.S. Department of Agriculture, Agricultural Research Service, Water Management Research Laboratory, 9611 South Riverbend Avenue, Parlier, CA 93648

\begin{abstract}
Additional index words. Prunus persica, evapotranspiration, microirrigation, soil water content, stem water potential, water relations
\end{abstract}

\begin{abstract}
A 3-year study was done to determine the effects of furrow, microspray, surface drip, and subsurface drip irrigation on production and fruit quality in mature 'Crimson Lady' peach [Prunus persica (L.) Batsch] trees. Furrow and microspray irrigations were scheduled weekly or biweekly, which is common practice in central California, while surface and subsurface drip irrigations were scheduled daily. Trees were maintained at similar water potentials following irrigation by adjusting water applications as needed. Tree size and fruit number were normalized among treatments by pruning and thinning each season. Surface and subsurface drip produced the largest fruit on average and the highest marketable yields among treatments. Drip benefits appeared most related to the ability to apply frequent irrigations. Whether water was applied above or below ground, daily irrigations by drip maintained higher soil water content within the root zone and prevented cycles of water stress found between less-frequent furrow and microspray irrigations. With furrow and microsprays, midday tree water potentials reached as low as $-1.4 \mathrm{MPa}$ between weekly irrigations and $-1.8 \mathrm{MPa}$ between biweekly irrigations, which likely accounted for smaller fruit and lower yields in these treatments. To reduce water stress, more frequent irrigation is probably impractical with furrow systems but is recommended when irrigating during peak water demands by microspray.
\end{abstract}

Irrigation is required to profitably grow peaches in many of the world's major production regions, including those in the U.S. Even in areas with relatively high rainfall, irrigation often increases fruit size and yield and accelerates fruit ripening (e.g., Layne and Tan, 1984). Common irrigation methods include traditional flood systems, such as furrows, borders, and

Received for publication 18 May 2005. Accepted for publication 6Aug. 2005. Research was funded in part by the California State Univ. Agriculture Research Initiative. We thank Paul Schreiner and Carolyn Scagel for helpful comments on the manuscript. Mention of a trademark, proprietary product, or vendor does not constitute a guarantee or warranty of the product by the U.S. Dept. of Agriculture and does not imply its approval to the exclusion of other products or vendors that also may be suitable.

${ }^{1}$ To whom reprint requests should be addressed. Current address: USDA-ARS Horticultural Crops Research Unit, 3420 NW Orchard Ave., Corvallis, OR 97330; e-mail brylad@onid.orst.edu.

${ }^{2}$ Former graduate student, California State Univ., Fresno. of irrigation water beneficially used by a crop in a specified area to the volume of irrigation water delivered to this area, is reduced when a portion of the water percolates below the effective root zone of the crop, evaporates from the soil surface, runs off the field, or is carried by wind beyond field boundaries (Jensen et al., 1990). Orchards irrigated with inefficient systems thus require more water to maintain favorable water status throughout the field as those irrigated with more efficient systems. Microsprays had much lower irrigation efficiency than other systems in young peach orchards due to high rates of soil evaporation after irrigation (Bryla et al., 2003; Layne et al., 1996). Drip systems, on the other hand, typically have high irrigation efficiency (when properly maintained) and also permit very frequent irrigations (Camp, 1998), which can improve water status of a crop by reducing water stress between irrigations (Radin et al., 1989). The benefits of frequent, uniform water applications are sometimes negated, however, by improper water placement. For example, 21-year-old grapefruit trees irrigated daily by drip experienced significantly more water stress than trees irrigated every 7 to $20 \mathrm{~d}$ by overhead sprinkler irrigation (Zekri and Parsons, 1988). In this case, the drip system wet only a fraction of the root system and was therefore unable to meet evapotranspiration requirements of the trees. Water placement, however, appears much less critical in peach because experience has shown that wetting only $20 \%$ to $30 \%$ of the potential root zone of mature trees is sufficient to maximize production, provided sufficient water is applied to meet tree water requirements (Tan and Buttery, 1982).

The objective of the present study was to evaluate the potential of various irrigation systems to reduce water stress and improve production and/or fruit quality in mature peach trees. Information presented here continues to follow treatments from our earlier study (Bryla et al., 2003) as the trees approached their fullbearing potential. Plant and soil water status was monitored in each treatment to identify any water constraints to fruit development throughout the season. sprinklers and microsprays. Low-volume drip systems are also used, but are not nearly as common. See Kruse et al. (1990) for a general description and comparisons of each system. In California, most growers using flood systems apply irrigation 2 to 4 times per month, depending on weather and water availability, while those using sprinklers and microsprays typically irrigate weekly. Drip irrigation is usually applied daily, especially during late spring and summer months.

Recently, we found that growth and production of young peach trees was significantly affected by irrigation method (Bryla et al., 2003). During the first 3 years after planting, trees irrigated by surface or subsurface drip were generally larger and produced higher yields than those irrigated by furrow or microsprays. Growth and production differences were largely attributed to differences in irrigation efficiency, irrigation frequency, and water placement with each system. Irrigation efficiency, defined as the ratio of the volume

\section{Materials and Methods}

Study site. The study was conducted in a 1.6-ha field of early-season 'Crimson Lady' peach (Prunus persica (L.) Batsch) trees on 'Nemaguard' rootstock. The field was planted in Apr. 1999 at the USDA-ARS San Joaquin Valley Agricultural Research Center in Parlier, Calif. Soil at the site is a Hanford fine sandy loam overlying a dense hardpan layer located 1.9 to $2.1 \mathrm{~m}$ deep. Trees were spaced $1.8 \mathrm{~m}$ apart within rows and $4.9 \mathrm{~m}$ apart between rows and pruned to a perpendicular- $\mathrm{V}$ training system (DeJong et al., 1994).

Experimental design. Trees were irrigated by furrow, microspray, surface drip, or subsurface drip. Furrow irrigation was applied weekly or biweekly in 1-m wide furrows located on each side of the tree row, $0.5 \mathrm{~m}$ from the tree trunk. Microspray irrigation was applied weekly with one $40 \mathrm{~L} \cdot \mathrm{h}^{-1}$ Fan-Jet emit- 
ter (about $4 \mathrm{~m}$ in diameter, $230^{\circ}$ spray pattern; Bowsmith, Inc., Exeter, Calif.) located near the base of each tree. Surface and subsurface drip irrigation was applied daily (in 2.5-mm increments) using ROOTGAURD drip tubing (Toro Ag Irrigation, El Cajon, Calif.) with 2 $\mathrm{L} \cdot \mathrm{h}^{-1}$ turbulent-flow emitters spaced every 0.45 $\mathrm{m}$ apart. Surface drip tubing (one lateral per row) was located near the tree trunks along the tree row. Subsurface drip tubing (two laterals per row) was buried $0.45 \mathrm{~m}$ deep on each side of the tree row, $1.1 \mathrm{~m}$ from the tree trunks. The irrigation methods were arranged at the site in a randomized complete block design with six replications per treatment. Each replication consisted of three rows of eight trees. Measurements were made on the middle six trees only.

Orchard management. Irrigations were scheduled based on crop evapotranspiration $\left(\mathrm{ET}_{c}\right)$ measured hourly on well-watered peach trees growing in a weighing lysimeter and monitored using turbine water meters (models SR-II and W-120; Invensys Metering Systems, Uniontown, Pa.) installed at the inflow of each irrigation system. This approach used actual tree water use data, making it relatively easy, especially with drip, to apply water to match $\mathrm{ET}_{\mathrm{c}}$ throughout the season. The lysimeter was located in a 1.4-ha peach field about 0.5 $\mathrm{km}$ from the site and contained two trees of the same variety or rootstock, age, planting density, and training system as trees grown in the present study (see Johnson et al., 2002, for details). Lysimeter trees were irrigated by subsurface drip.

Trees were fertilized with $32 \%$ urea ammonium nitrate solution (UAN32) at a rate of 45 to $60 \mathrm{~kg} \mathrm{~N} /$ ha per year the first 3 years after planting and $80 \mathrm{~kg} \mathrm{~N} / \mathrm{ha}$ per year thereafter. Fertilizer was injected continuously from April to August into microspray and drip systems and shanked into furrows in three equal doses applied in April, August, and September. Trees were summer pruned in June and dormant pruned in January. Canopy size, measured as shaded area, was similar among treatments following each pruning (data not shown). Fruit were commercially thinned to about the same number of fruit per tree each spring and harvested between late May and early June.
Harvest required two to three pickings per year. Weeds, insects and diseases were controlled with herbicides and pesticides as needed.

Measurements. All measurements reported in the present study were made during the fourth through sixth (2002-04) growing seasons.

Soil water content was measured periodically at $0.2,0.4,0.8,1.2,1.6$, and $2.0 \mathrm{~m}$ depths using a calibrated neutron probe (series 4300 ; Troxler International, LTD., Research Triangle Park, N.C.) and galvanized steel access tubes. One tube was installed per replication at or near the middle of the center row of the plot. Exact location of the access tubes varied with treatment to account for differences in the method of water application: furrow treatments had tubes installed in the middle of a furrow; microspray treatments had tubes installed $1 \mathrm{~m}$ from a microspray emitter; and drip treatments had tubes installed adjacent to a drip emitter. Root excavations done at the completion of the study indicated that $>90 \%$ roots in each treatment were located at $<1 \mathrm{~m}$.

Stem water potential was measured periodically using a pressure chamber (model 3000-1412; Soilmoisture Equipment Corp., Santa Barbara, Calif.) following guidelines outlined by McCutchan and Shackel (1992). Measurements were taken at midday (from 1200 to $1400 \mathrm{HR}$ ) on shaded leaves enclosed at least $1 \mathrm{~h}$ in black plastic bags covered with aluminum foil. Two leaves were measured per replication on each sample date.

Fruit were counted and weighed at each harvest and measured for size and percent red color using an automatic fruit sorter (Autoline Fruit Sorting Systems, Reedley, Calif.). Twenty fruit per replication were also assessed for flesh firmness, water content, soluble solids, $\mathrm{pH}$, and titratable acidity at harvest (each year) and after $1,2,3$, and 4 weeks of storage at 0 or $5^{\circ} \mathrm{C}$ (in 2002 only). Ten of the stored fruit were tested immediately after removal from storage each week while the other 10 were ripened at $20^{\circ} \mathrm{C}$ for $5 \mathrm{~d}$ before testing. Flesh firmness of each fruit was measured first using a U.C. firmness tester with an 8-mm tip (Western Industrial Supply, San Francisco, Calif.). Skin from opposite cheeks of each fruit was removed and firmness was calculated as an average of two measurements. A $2.5-\mathrm{cm}$ wedge was then removed from each fruit, weighed fresh, dried at $60^{\circ} \mathrm{C}$ for at least $48 \mathrm{~h}$, and reweighed to determine fruit water content, calculated as the ratio of fruit water to total fruit weight. Remaining flesh was removed from the pit, juiced using a hand press, filtered through cheesecloth, and combined to form a composite juice sample for each treatment. Soluble solids concentration and $\mathrm{pH}$ of the juice samples were measured using an American Optical refractometer with automatic temperature compensation and a Mettler Toledo $\mathrm{pH}$ meter, respectively. Titratable acidity was finally measured by titrating a 6-g sample of juice diluted with 50 $\mathrm{mL}$ of deionized water with $0.1 \mathrm{~N} \mathrm{NaOH}$ to an endpoint of $8.2 \mathrm{pH}$.

Statistical analysis. Growth and production data were analyzed by analysis of variance (ANOVA) using ProcGLM (SAS Institute, Cary, N.C.) procedures. Means were separated at the 0.05 level using Fisher's protected least significant difference (LSD) test.

\section{Results}

Irrigation requirements. The weighing lysimeter indicated that the trees required 998 to $1064 \mathrm{~mm}$ of water each growing season (Table 1). However, additional water was needed by microsprays to compensate for soil evaporation (Table 1) and maintain similar water status among treatments (Fig. 1A). Most of the additional water was added in early spring prior to full canopy development. By summer, all treatments received an average of 4 to $10 \mathrm{~mm}$ of water per day (depending on weather conditions), equaling about 33 to $88 \mathrm{~L} /$ tree per day, which is usual for mature peach trees planted at high density (Ayars et al., 2003).

Vegetative growth and production. The effect of irrigation method on growth and production varied from year to year depending on tree age and weather conditions. Pruning weight, for example, was significantly affected by irrigation method only in 2002 (fourth season) before trees had reached full maturity (Table 2). Marketable yield, on the other hand, was significantly affected by irrigation method in 2002 and 2004 (Table 3) when spring conditions were drier during fruit development (Table 1).

Table 1. Crop evapotranspiration (ET), precipitation, and irrigation applied to 'Crimson Lady' peach trees during 2002-04.

\begin{tabular}{|c|c|c|c|c|c|c|c|c|c|}
\hline \multirow[b]{2}{*}{ Month } & \multicolumn{3}{|c|}{$\mathrm{ET}_{\mathrm{c}}(\mathrm{mm})^{\mathrm{z}}$} & \multicolumn{3}{|c|}{ Precipitation $(\mathrm{mm})^{\mathrm{y}}$} & \multicolumn{3}{|c|}{ Irrigation $(\mathrm{mm})^{\mathrm{x}}$} \\
\hline & 2002 & 2003 & 2004 & 2002 & 2003 & 2004 & 2002 & 2003 & 2004 \\
\hline February & 8 & 13 & 10 & 6 & 35 & 57 & 0 & 0 & 0 \\
\hline April & 56 & 54 & 76 & 7 & 54 & 0 & $58(98)$ & $28(30)$ & 65 (109) \\
\hline May & 152 & 125 & 150 & 2 & 17 & 1 & $116(223)$ & $110(117)$ & $148(234)$ \\
\hline June & 204 & 193 & 182 & 0 & 0 & 0 & $170(213)$ & $188(228)$ & $180(210)$ \\
\hline July & 240 & 227 & 210 & 0 & 0 & 0 & $261(261)$ & $222(222)$ & $212(212)$ \\
\hline October & 84 & 114 & 86 & 0 & 0 & 53 & $46(46)$ & $62(84)$ & $46(46)$ \\
\hline November & 8 & 20 & 12 & 52 & 16 & 22 & 0 & 0 & 0 \\
\hline December & 2 & 1 & 3 & 46 & 55 & 76 & 0 & 0 & 0 \\
\hline Total & 1142 & 1140 & 1095 & 167 & 209 & 255 & 1029 & 940 & 992 \\
\hline
\end{tabular}

${ }^{2}$ Measured with a weighing lysimeter.

yobtained from a nearby CIMIS weather station (Station No. 39, Parlier, Calif.)

Irrigation was applied 2 Apr. to 14 Oct. 2002, 26 Mar. to 15 Oct. 2003, and 1 Apr. to 13 Oct. 2004. Main numbers indicate water applied to trees irrigated by furrow, surface drip, and subsurface drip; numbers in parentheses indicate water applied to trees irrigated by microsprays. 
Surface and subsurface drip generally produced the heaviest pruning weights among treatments and the highest marketable yields. Higher yields were mostly attributed to larger fruit size (Table 3). With few exceptions, trees irrigated by surface and subsurface drip had proportionally less fruit in the nonmarketable

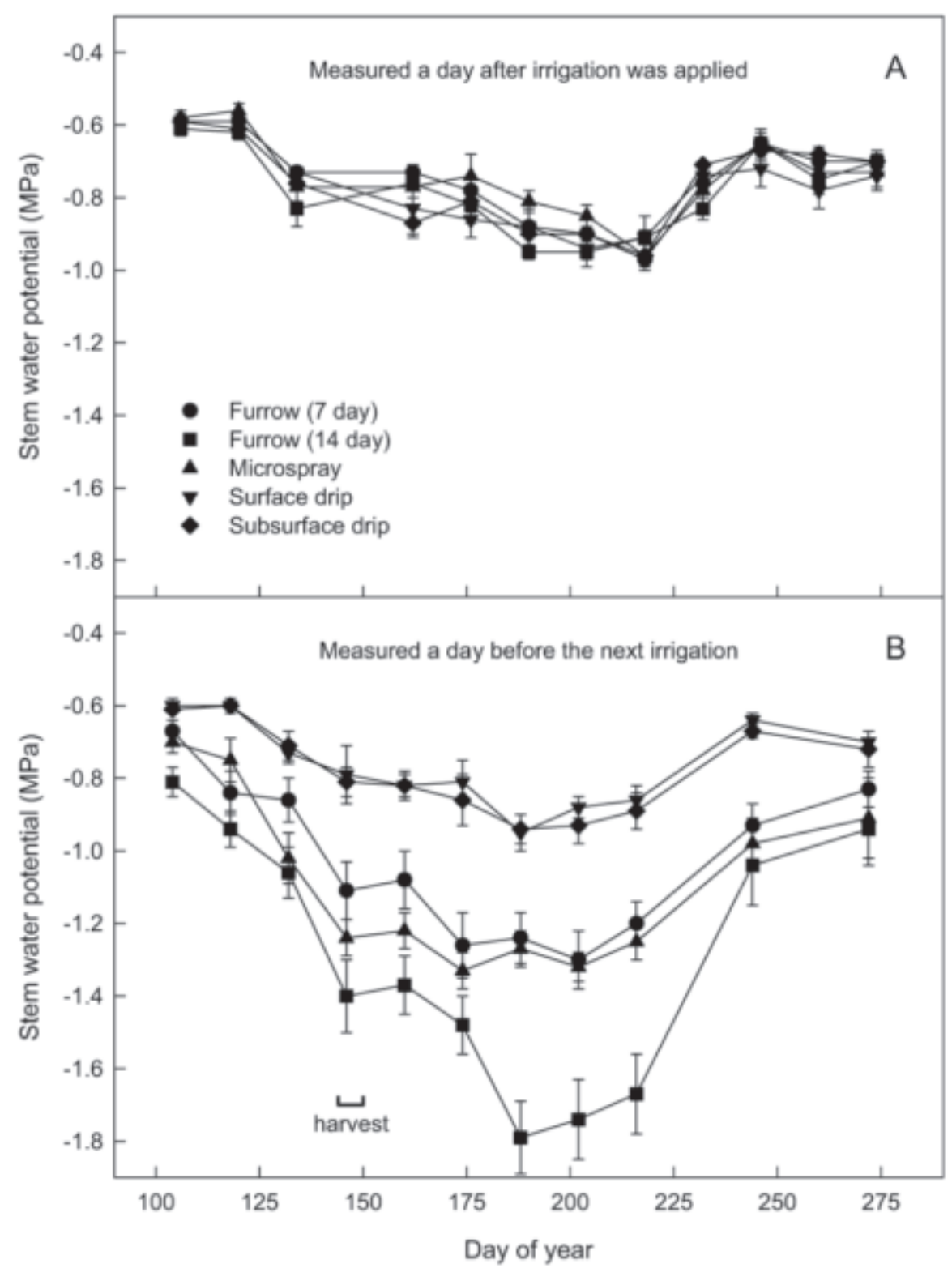

Fig. 1. Midday stem water potential of 'Crimson Lady' peach trees irrigated by furrow (every 7 or $14 \mathrm{~d}$ ), microspray, surface drip, or subsurface drip. Measurements were made (A) $1 \mathrm{~d}$ after irrigation was applied and (B) $1 \mathrm{~d}$ before the next irrigation, every 2 to 4 weeks throughout the 2002 season. Fruit were harvested on day of year 144, 148, and 150. Values are the mean of six replications and error bars represent $1 \mathrm{SE}$.

Table 2. Fresh pruning weights of 'Crimson Lady' peach trees irrigated by furrow (every 7 or $14 \mathrm{~d}$ ), microspray, surface drip, or subsurface drip.

\begin{tabular}{llcc}
\hline Irrigation & \multicolumn{3}{c}{${\text { Pruning wt }(\mathrm{kg} / \text { tree })^{\mathrm{z}}}$} \\
\cline { 2 - 4 } method & 2002 & 2003 & 2004 \\
\hline Furrow (7 d) & $17.8 \mathrm{ab}^{\mathrm{y}}$ & 17.6 & 13.5 \\
Furrow (14 d) & $16.1 \mathrm{~b}$ & 15.3 & 13.8 \\
Microspray & $16.0 \mathrm{~b}$ & 16.9 & 13.1 \\
Surface drip & $19.5 \mathrm{a}$ & 18.1 & 15.0 \\
Subsurface drip & $19.8 \mathrm{a}$ & 19.9 & 16.5 \\
$P$ value & 0.0070 & 0.0634 & 0.1711 \\
\hline
\end{tabular}

${ }^{\mathrm{z}}$ Summer and dormant pruning weights combined.

${ }^{y}$ Mean separation within columns by Fisher's protected LSD test, $P \leq 0.05$. rigation rates were adjusted in the study to maintain similar tree water status in each treatment. Stem water potentials measured within a day after irrigation were similar among irrigation treatments, ranging from -0.6 to $-1.0 \mathrm{MPa}$ throughout the 2002 season (Fig. 1A). Therefore, differences among treatments were more likely due to differences in irrigation frequency. Daily measurements indicated that stem water potentials declined quickly as soil water was depleted between furrow and microspray irrigations, reaching as low as $-1.4 \mathrm{MPa}$ during weekly irrigations and $-1.8 \mathrm{MPa}$ during biweekly irrigations, but remained high when trees were irrigated by surface or subsurface drip (Fig. 2). In fact, trees irrigated by furrow or microsprays experienced significantly lower stem water potentials than trees irrigated by surface or subsurface drip throughout most the season, including in late spring during fruit development (Fig. 1B). Frequent irrigations by surface and subsurface drip apparently prevented cycles of water stress and thereby reduced water limitations to growth and production.

Soil water content and stem water potential measurements were less intensive in 2003 and 2004, but results were similar to those measured in 2002 (data not shown). The only difference was that stem water potentials were somewhat higher in spring 2003 due to above average precipitation (Table 1), which likely accounts for the lack of difference in marketable yields observed in 2003 (Table 3).

Fruit quality and ripening. Aside from fruit size, irrigation method had only minor effects on other fruit quality characteristics measured. Fruit water content, soluble solids, $\mathrm{pH}$, acidity, and firmness varied from year to year, but were usually quite similar among irrigation treatments (Table 5). The only significant difference was that, in 2004, drip treatments produced fruit with higher water content and lower titratable acidity than trees irrigated biweekly by furrow. Fruit color was also similar among treatments, with one exception - furrow irrigation in 2002 produced slightly more fruit in the reddest color category than microspray or drip irrigation (Table 6).

Irrigation method likewise had little effect on fruit ripening, which is not surprising considering the few differences found in fruit quality. Repeated measuresANOVArevealed significant storage time effects on fruit ripening at $0^{\circ} \mathrm{C}(P$ $<0.0001)$ and $5^{\circ} \mathrm{C}(P<0.0001)$, as indicated by changes in flesh firmness, but no significant irrigation method effects or time $\times$ method interactions. Picked fruit basically ripened more quickly when stored at $5{ }^{\circ} \mathrm{C}$ than at $0{ }^{\circ} \mathrm{C}$, but ripening was similar among irrigation treatments (Fig. 3). Even when fruit were later moved to a $20^{\circ} \mathrm{C}$ market temperature for $5 \mathrm{~d}$, ripening was unaffected by the method of irrigation used to produce the fruit (data not shown).

\section{Discussion}

The most effective irrigation methods for increasing peach production in the present study were surface and subsurface drip. Through three growing seasons, these two methods 
increased average fruit size, reduced the number of nonmarketable fruit, and improved marketable yield by $9 \%$ to $22 \%$ over more methods (Tables 3 and 4). Drip also produced larger peaches than sprinklers in a study done in Texas (Reeder et al., 1979). In general, drip irrigation is well suited for high-density orchards, especially in medium to heavy-textured soils with good water-holding capacity (Evans and Proebsting, 1985; Middleton et al., 1979; Mitchell and Chalmers, 1983; Swietlik, 1992), but may be unsuitable for coarser-textured soils due to poor lateral movement of water from drip emitters. In fact, Andreu et al. (1997) found that surface drip irrigation was unable to meet tree water demands in almond grown on gravelly, sandy loam soil. Under these soil conditions, the trees produced more vegetative growth and yield with microspray irrigation than with irrigation by surface or subsurface drip (Schwankl et al., 1999). traditional furrow or microspray irrigation

The most apparent benefit of drip is that it maintained high soil water availability throughout the season, preventing cycles of water stress that occurred between furrow and microspray irrigations (Fig. 2). Such benefit would be particularly important during fruit development since even mild water stress can induce fresh fruit weight reductions in peach (Berman and DeJong, 1996; Daniell, 1982). Once peach growth is slowed from lack of soil water, growth loss is permanent and the final swell produces smaller fruit than when water supply is adequate (Crisosto et al., 1994; Li et al., 1989). Daily drip irrigation thus enabled peach to approach its full production potential for more days of the season. Applying more frequent irrigation is probably impractical (and uneconomical) with flood systems due to their design constraints, but may be possible with microspray systems, provided shorter irrigation intervals are not limited by cultural practices. However, even when irrigation intervals were

Table 3. Fruit production of 'Crimson Lady' peach trees irrigated by furrow (every 7 or $14 \mathrm{~d}$ ), microspray, surface drip, or subsurface drip. Measurements were made on fruit harvested 24 to 30 May 2002, 27 May to 3 June 2003, and 24 to 27 May 2004.

\begin{tabular}{|c|c|c|c|c|}
\hline Year & $\begin{array}{l}\text { Irrigation } \\
\text { method }\end{array}$ & $\begin{array}{l}\text { Crop load } \\
\text { (fruit/tree) }\end{array}$ & $\begin{array}{l}\text { Avg fruit } \\
\text { wt } \\
\text { (g/fruit) }\end{array}$ & $\begin{array}{c}\text { Marketable } \\
\text { yield } \\
(\mathrm{t} / \mathrm{ha})^{\mathrm{z}}\end{array}$ \\
\hline \multirow[t]{6}{*}{2002} & Furrow (7 d) & 127 & $137 b^{y}$ & $17.4 \mathrm{~b}$ \\
\hline & Furrow (14 d) & 125 & $135 \mathrm{~b}$ & $15.5 \mathrm{~b}$ \\
\hline & Microspray & 111 & $147 \mathrm{ab}$ & $16.5 \mathrm{~b}$ \\
\hline & Surface drip & 119 & $155 \mathrm{a}$ & $19.7 \mathrm{a}$ \\
\hline & Subsurface drip & 128 & $153 \mathrm{a}$ & $20.5 \mathrm{a}$ \\
\hline & $P$ value & 0.3155 & 0.0304 & 0.0004 \\
\hline \multirow[t]{6}{*}{2003} & Furrow (7 d) & 150 & $164 \mathrm{~b}$ & 25.4 \\
\hline & Furrow (14 d) & 156 & $162 \mathrm{~b}$ & 26.5 \\
\hline & Microspray & 147 & $168 \mathrm{ab}$ & 25.6 \\
\hline & Surface drip & 162 & $166 \mathrm{ab}$ & 28.6 \\
\hline & Subsurface drip & 149 & $175 \mathrm{a}$ & 26.9 \\
\hline & $P$ value & 0.1154 & 0.0112 & 0.2540 \\
\hline \multirow[t]{6}{*}{2004} & Furrow (7 d) & 197 & $137 \mathrm{ab}$ & 19.8 a \\
\hline & Furrow (14 d) & 194 & $129 \mathrm{~b}$ & $15.9 \mathrm{~b}$ \\
\hline & Microspray & 196 & $125 \mathrm{~b}$ & $16.7 \mathrm{~b}$ \\
\hline & Surface drip & 193 & $141 \mathrm{a}$ & $22.1 \mathrm{a}$ \\
\hline & Subsurface drip & 186 & $141 \mathrm{a}$ & 20.7 a \\
\hline & $P$ value & 0.5073 & 0.0424 & 0.0005 \\
\hline
\end{tabular}

${ }^{\mathrm{z}}$ Marketable fruit were $\geq 57 \mathrm{~mm}$ in diameter.

y Mean separation within columns and year by Fisher's protected LSD test, $P \leq 0.05$.

Table 4. Fruit size distribution of 'Crimson Lady' peaches from trees irrigated by furrow (every 7 or 14 d), microspray, surface drip, or subsurface drip. Measurements were made on fruit harvested 24 to 30 May 2002, 27 May to 3 June 2003, and 24 to 27 May 2004.

\begin{tabular}{llccccc}
\hline \multirow{2}{*}{ Year } & Irrigation & \multicolumn{5}{c}{ Fruit size distribution (\%) } \\
\cline { 2 - 6 } 2002 & method & $<57 \mathrm{~mm}$ & $57-64 \mathrm{~mm}$ & $65-70 \mathrm{~mm}$ & $71-76 \mathrm{~mm}$ & $>76 \mathrm{~mm}$ \\
\hline & Furrow (7 d) & $11.5 \mathrm{~b}^{\mathrm{z}}$ & $19.9 \mathrm{ab}$ & 49.9 & $18.5 \mathrm{~b}$ & $0.1 \mathrm{~b}$ \\
& Furrow (14 d) & $16.8 \mathrm{a}$ & $21.0 \mathrm{a}$ & 46.5 & $15.6 \mathrm{~b}$ & $0.1 \mathrm{~b}$ \\
& Microspray & $8.7 \mathrm{bc}$ & $20.4 \mathrm{a}$ & 44.0 & $26.3 \mathrm{ab}$ & $0.6 \mathrm{ab}$ \\
& Surface drip & $4.1 \mathrm{c}$ & $11.9 \mathrm{c}$ & 47.7 & $35.5 \mathrm{a}$ & $0.7 \mathrm{a}$ \\
& Subsurface drip & $6.2 \mathrm{c}$ & $14.0 \mathrm{bc}$ & 47.9 & $31.2 \mathrm{a}$ & $0.6 \mathrm{ab}$ \\
& P value & 0.0003 & 0.0109 & 0.4657 & 0.0177 & 0.0365 \\
& Furrow (7 d) & 7.2 & 14.8 & 47.7 & $30.0 \mathrm{~b}$ & 0.3 \\
& Furrow (14 d) & 5.3 & 10.2 & 49.6 & $34.4 \mathrm{ab}$ & 0.6 \\
& Microspray & 6.5 & 12.3 & 44.8 & $35.6 \mathrm{ab}$ & 0.8 \\
& Surface drip & 5.0 & 14.2 & 44.8 & $34.7 \mathrm{ab}$ & 1.3 \\
& Subsurface drip & 4.4 & 9.7 & 40.5 & $43.6 \mathrm{a}$ & 1.8 \\
& P value & 0.3686 & 0.1827 & 0.1098 & 0.0373 & 0.0677 \\
& Furrow (7 d) & $25.1 \mathrm{ab}$ & $31.8 \mathrm{~b}$ & $35.0 \mathrm{ab}$ & $8.1 \mathrm{ab}$ & 0.0 \\
& Furrow (14 d) & $34.0 \mathrm{a}$ & $29.5 \mathrm{~b}$ & $30.4 \mathrm{~b}$ & $6.1 \mathrm{ab}$ & 0.0 \\
& Microspray & $28.2 \mathrm{a}$ & $38.6 \mathrm{a}$ & $29.8 \mathrm{~b}$ & $3.4 \mathrm{~b}$ & 0.0 \\
& Surface drip & $19.1 \mathrm{~b}$ & $28.5 \mathrm{~b}$ & $41.5 \mathrm{a}$ & $10.8 \mathrm{ab}$ & 0.1 \\
& Subsurface drip & $17.4 \mathrm{~b}$ & $27.0 \mathrm{~b}$ & $43.6 \mathrm{a}$ & $11.8 \mathrm{a}$ & 0.1 \\
& $P$ value & 0.0036 & 0.0267 & 0.0066 & 0.0234 & 0.5324 \\
\hline
\end{tabular}

${ }^{\mathrm{z}}$ Mean separation within columns and year by Fisher's protected LSD test, $P \leq 0.05$. shortened to every $3 \mathrm{~d}$, almond trees irrigated by microsprays had lower water potentials during periods of peak water demand than those irrigated daily by drip (Edstrom and Schwankl, 2004). Since water potential is well correlated to production and fruit size in tree fruit (Naor, 2001; Naor et al., 1995, 1999), lower water potentials between irrigations may be most critical in midseason varieties that ripen during summer months, especially in trees with heavy crop loads during Stage III of fruit development (Lampinen et al., 1995, Marsal et al., 2005; Naor et al., 2001). The cultivar used in the present study was an early-season variety that ripened in late May to early June.

Production benefits of drip may also lie in the response of peach to restricted root volumes (Boland et al., 2000a, 2000b). Root systems are typically confined by drip because it wets only a fraction of the soil volume wetted by other systems (Mitchell and Chalmers, 1983). Root confinement appears to limit vegetative growth in peach (due to a balance between root and shoot growth) without limiting photosynthesis (Mandre et al., 1995; Tan and Buttery, 1982; Williamson et al., 1992). This process, as a result, increases the availability of assimilates for fruit production (Chalmers, 1988; Erez et al., 1992) and may be one mechanism by which drip increases fruit size over furrow or microspray irrigation in peach. Vegetative growth was less responsive to drip irrigation as the trees matured in the present study (Table 2), which, according to this hypothesis, may have increased availability of assimilates for fruit production.

Another explanation of these results may partially lie in root responses to soil water stress. For example, Radin et al. (1989) partly attributed water stress at longer irrigation intervals to diminished root function in cotton. Water stress can accelerate root system decline in some species by increasing stress-induced root turnover (Eissenstat et al., 2000; Pregitzer et al., 1993). However, rapid recovery of water potentials following furrow or microspray irrigation indicates that root function was not compromised by cyclical water stress in peach. Whether trees were irrigated weekly or biweekly, stem water potentials were similar to those of trees irrigated daily by drip within a day or so after rewatering (Fig. 2).

Production was apparently not affected by lateral arrangement because yield and fruit quality were similar whether irrigation was applied by surface drip with one lateral or subsurface drip with two laterals. Growth and yield were also similar between trees irrigated with one surface drip and two subsurface drip laterals in almond (Edstrom and Schwankl, 2004). Such similarities between drip methods are somewhat surprising since subsurface drip wet nearly twice the soil volume as surface drip. Evidently, lateral number and location has little effect on tree fruit production as long as the system can provide enough water to meet evapotranspiration demands. However, fewer laterals reduce system costs (Bryla et al., 2005), while multiple laterals increase root system development in the soil profile (D. Bryla, 

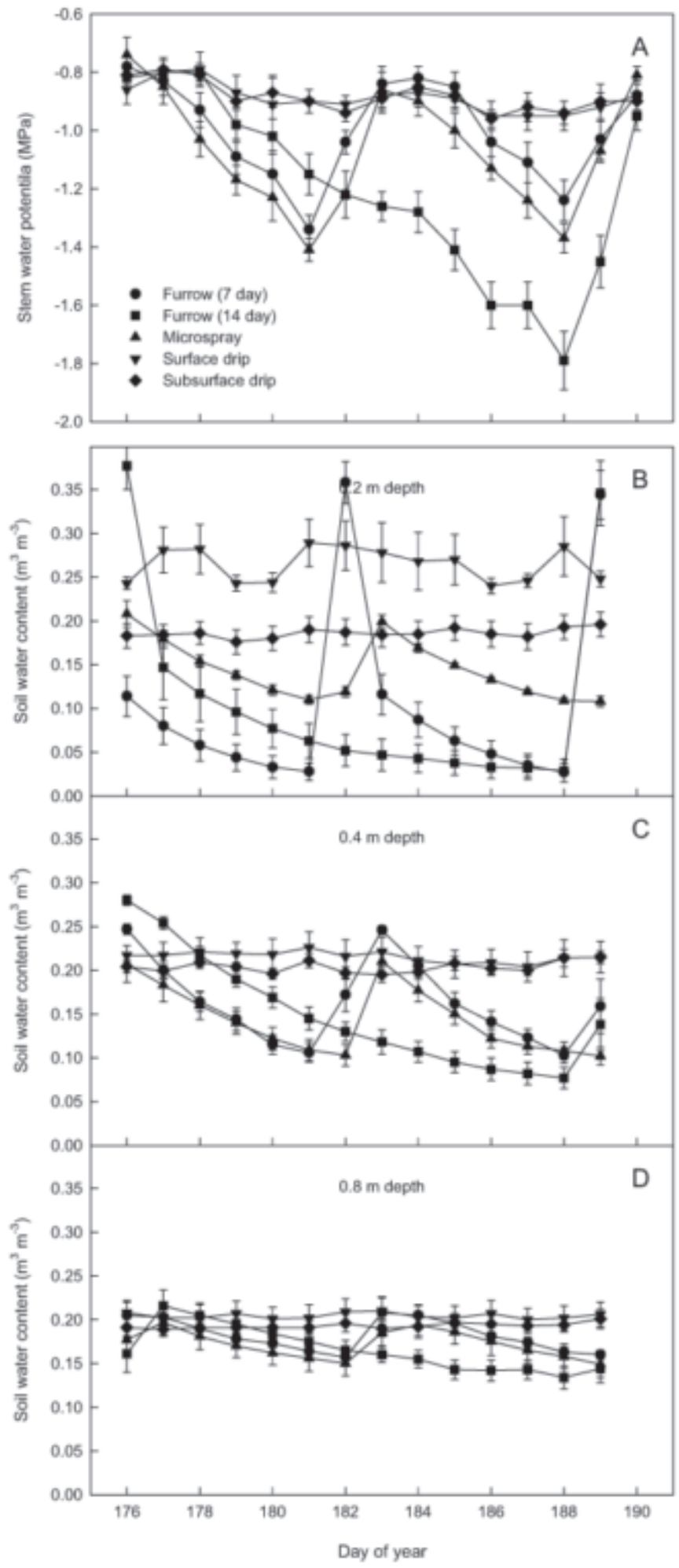

Fig. 2. Daily changes in (A) stem water potential and soil water content at (B) 0.2, (C) 0.4, and (D) $0.8 \mathrm{~m}$ soil depths in 'Crimson Lady' peach trees irrigated by furrow (every 7 or $14 \mathrm{~d}$ ), microspray, surface drip, or subsurface drip. No change in soil water content were observed in each treatment at depths $>0.8 \mathrm{~m}$. Measurements were made 25 June to 9 July 2002. Furrow (7 d) and microspray irrigations were applied on day of year (DOY) 175,182 , and 189; furrow (14 d) irrigations were applied DOY 175 and 189; surface and subsurface drip irrigations were applied daily. Values are the mean of six replications and error bars represent $1 \mathrm{SE}$. unpublished data) and thereby potentially reduce the risk of excessive water stress during irrigation system failures. Optimum lateral arrangement clearly varies from site to site depending on soil type and cultural practices. Further study is needed to identify the best drip lateral arrangements for maximizing root efficiency in tree crops.

\section{Literature Cited}

Andreu, L., J.W. Hopmans, and L.J. Schwankl. 1997. Spatial and temporal distribution of soil water balance of a drip-irrigated almond tree. Agr. Water Mgt. 35:123-146.

Ayars, J.E., R.S. Johnson, C.J. Phene, T.J. Trout, D.A. Clark, and R.M. Mead. 2003. Water use by drip-irrigated late-season peaches. Irr. Sci. 22:187-194.

Berman, M.E. and T.M. DeJong. 1996. Water stress and crop load effects on fresh and dry weights in peach (Prunus persica). Tree Physiol. 16:859-864.

Boland, A.M., P.H. Jerie, P.D. Mitchell, I. Goodwin, and D.J. Connor. 2000a. Long-term effects of restricted root volume and regulated deficit irrigation on peach. I. Growth and mineral nutrition. J. Amer. Soc. Hort. Sci. 125:135-142.

Boland, A.M., P.H. Jerie, P.D. Mitchell, I. Goodwin, and D.J. Connor. 2000b. Long-term effects of restricted root volume and regulated deficit irrigation on peach. I. Productivity and water use. J. Amer. Soc. Hort. Sci. 125:143-148.

Bryla, D.R., T.J. Trout, J.E. Ayars, and R.S. Johnson. 2003. Growth and production of young peach trees irrigated by furrow, microspray, surface drip, or subsurface drip systems. HortScience 38:1112-1116.

Bryla, D.R., J. Gartung, T. Trout, R.S. Johnson, and J.E. Ayars. 2005. Drip irrigation improves potential profits for growing peach. Proc. Calif. Agron. Soc. Amer., 1-2 Feb. 2005. Modesto, Calif.

Camp, C.R. 1998. Subsurface drip irrigation: A review. Trans. Amer. Soc. Agr. Eng. 41:13531367.

Chalmers, D.J. 1988. The role of root growth in regulation of assimilate partitioning and productivity of annual and perennial crops. Proc. 4th Intl. Congr. Micro-Irrigation Australia, Oct. 1988, Albury-Wodonga.

Crisosto, C.H., R.S. Johnson, J.G. Luza, and G.M. Crisosto. 1994. Irrigation regimes affect fruit soluble solids concentration and rate of water loss of 'O'Henry' peaches. HortScience 29:1169-1171.

Daniell, J.W. 1982. Effect of trickle irrigation on growth and yield of 'Loring' peach trees. J. Hort. Sci. 57:393-399.

DeJong, T.M., K.R. Day, J.F. Doyle, and R.S. Johnson. 1994. The Kearney Agricultural Center perpendicular "V" (KAC-V) orchard system for peaches and nectarines. HortTechnology $4: 362-367$.

Edstrom, J. and Schwankl, L. 2004. Nickels Soil Lab project, p. 337-346. In: Years of discovery. Acompendium of production and environmental research projects, 1972-2003. Almond BoardCalif., Modesto.

Eissenstat, D.M., C.E. Wells, R.D. Yanai, and J.L. Whitbeck. 2000. Building roots in a changing environment: implications for root longevity. New Phytol. 147:33-42.

Evans, R.G. and Proebsting, E.L. 1985. Response of red delicious apples to trickle irrigation, $\mathrm{p}$. 231-239. In: Proc. 3rd Intl. Drip/Trickle Irr. Congr. vol. 1, 18-21 Nov. 1985. Fresno, Calif.

Erez, A., Y. Ran, and B. Bar-Yosef. 1992. The effect of restricted root volume on the development, 
Table 5. Fruit quality characteristics of 'Crimson Lady' peaches from trees irrigated by furrow (every 7 or

14 d), microspray, surface drip, or subsurface drip. Measurements were made on fruit harvested on 28 May 2002 (second picking), 30 May 2003 (second picking), and 24 May 2004 (first picking).

\begin{tabular}{llccccc}
\hline Year & Irrigation & $\begin{array}{c}\text { Flesh } \\
\text { method }\end{array}$ & $\begin{array}{c}\text { Soluble } \\
\text { solids } \\
(\%)\end{array}$ & $\begin{array}{c}\text { Juice } \\
\mathrm{pH}\end{array}$ & $\begin{array}{c}\text { Titratable } \\
\text { acidity } \\
(\mathrm{meq} / \mathrm{L})\end{array}$ & $\begin{array}{c}\text { Water } \\
\text { content } \\
(\%)\end{array}$ \\
\hline 2002 & Furrow (7 d) & 38.9 & 9.7 & 3.50 & 115 & 85.3 \\
& Furrow (14 d) & 38.7 & 10.8 & 3.52 & 107 & 84.5 \\
& Microspray & 38.2 & 9.8 & 3.54 & 118 & 85.3 \\
& Surface drip & 40.1 & 9.9 & 3.47 & 113 & 85.6 \\
& Subsurface drip & 37.8 & 10.0 & 3.50 & 114 & 84.9 \\
& $P$ value & 0.6875 & 0.3925 & 0.2043 & 0.2975 & 0.1116 \\
2003 & Furrow (7 d) & 35.6 & 10.1 & 3.52 & 119 & 85.9 \\
& Furrow (14 d) & 35.8 & 10.0 & 3.53 & 118 & 85.5 \\
& Microspray & 33.0 & 9.9 & 3.42 & 123 & 85.9 \\
& Surface drip & 33.4 & 9.5 & 3.42 & 119 & 86.3 \\
& Subsurface drip & 35.5 & 9.8 & 3.50 & 117 & 86.3 \\
& $P$ value & 0.6792 & 0.5602 & 0.0667 & 0.8194 & 0.6115 \\
& Furrow (7 d) & 24.4 & 11.9 & 3.56 & $100 \mathrm{~b}$ & $83.4 \mathrm{bc}$ \\
& Furrow (14 d) & 21.6 & 12.2 & 3.53 & $109 \mathrm{a}$ & $83.2 \mathrm{c}$ \\
& Microspray & 22.5 & 11.3 & 3.53 & $104 \mathrm{ab}$ & $83.8 \mathrm{abc}$ \\
& Surface drip & 22.2 & 11.0 & 3.55 & $97 \mathrm{~b}$ & $84.3 \mathrm{ab}$ \\
& Subsurface drip & 24.2 & 11.5 & 3.54 & $96 \mathrm{~b}$ & $84.5 \mathrm{a}$ \\
& $P$ value & 0.1757 & 0.1438 & 0.9115 & 0.0263 & 0.0379 \\
\hline
\end{tabular}

${ }^{2}$ Mean separation within columns and year by Fisher's protected LSD test, $P \leq 0.05$.

Table 6. Fruit color distribution of 'Crimson Lady' peaches from trees irrigated by furrow (every 7 or 14 d), microspray, surface drip, or subsurface drip. Measurements were made on fruit harvested 24 to 30 May 2002, 27 May to 3 June 2003, and 24 to 27 May 2004.

\begin{tabular}{|c|c|c|c|c|c|c|}
\hline \multirow[b]{2}{*}{ Year } & \multirow{2}{*}{$\begin{array}{l}\text { Irrigation } \\
\text { method }\end{array}$} & \multicolumn{5}{|c|}{ Fruit color distribution (\%) } \\
\hline & & $<20 \%$ red & $20 \%-40 \%$ re & $0 \%-60 \% \mathrm{r}$ & $0 \%-80 \%$ red & $>80 \%$ red \\
\hline \multirow[t]{6}{*}{2002} & Furrow $(7 \mathrm{~d})$ & 7.0 & 36.2 & 39.4 & 15.4 & $1.9 \mathrm{a}^{\mathrm{z}}$ \\
\hline & Furrow (14 d) & 7.6 & 35.0 & 38.5 & 16.8 & $2.2 \mathrm{a}$ \\
\hline & Microspray & 6.3 & 38.4 & 40.7 & 13.8 & $0.9 \mathrm{~b}$ \\
\hline & Surface drip & 9.2 & 36.9 & 40.4 & 12.8 & $0.6 \mathrm{~b}$ \\
\hline & Subsurface drip & 8.4 & 39.2 & 39.8 & 12.0 & $0.6 \mathrm{~b}$ \\
\hline & $P$ value & 0.4168 & 0.1925 & 0.5680 & 0.0868 & 0.0061 \\
\hline \multirow[t]{6}{*}{2003} & Furrow $(7 \mathrm{~d})$ & 14.5 & 43.1 & 32.9 & 8.8 & 0.6 \\
\hline & Furrow (14 d) & 16.9 & 41.3 & 31.9 & 9.5 & 0.4 \\
\hline & Microspray & 13.0 & 41.5 & 35.8 & 8.6 & 1.0 \\
\hline & Surface drip & 12.7 & 41.6 & 34.1 & 11.1 & 0.6 \\
\hline & Subsurface drip & 15.0 & 41.6 & 33.5 & 9.2 & 0.6 \\
\hline & $P$ value & 0.4860 & 0.9543 & 0.7315 & 0.6612 & 0.4222 \\
\hline \multirow[t]{6}{*}{2004} & Furrow (7 d) & 3.4 & 13.4 & 30.8 & 36.2 & 16.2 \\
\hline & Furrow (14 d) & 4.4 & 16.0 & 30.7 & 35.6 & 13.3 \\
\hline & Microspray & 3.1 & 12.3 & 30.0 & 37.8 & 16.8 \\
\hline & Surface drip & 2.6 & 11.5 & 28.2 & 38.3 & 19.4 \\
\hline & Subsurface drip & 3.7 & 13.6 & 31.5 & 34.4 & 16.8 \\
\hline & $P$ value & 0.0994 & 0.1515 & 0.3095 & 0.0725 & 0.1535 \\
\hline
\end{tabular}

${ }^{2}$ Mean separation within columns and year by Fisher's protected LSD test, $P \leq 0.05$.

yield and dry-matter partitioning in young fruiting peach trees. Acta Hort. 322:199-214.

Jensen, M.E., W.R. Rangeley, and P.J. Dieleman. 1990. Irrigation trends in world agriculture, $\mathrm{p}$. 31-67. In: B.A. Stewart and D.R. Nielson (eds.). Irrigation of agricultural crops. ASA-CSSASSSA Publ. Agron. Monogr. 30.

Johnson, R.S., J. Ayars, and T. Hsiao. 2002. Modeling young peach tree evapotranspiration. Acta Hort. 584:107-113.

Kruse, E.G., D.A. Bucks, and R.D. von Bernuth. 1990. Comparison of irrigation systems, $\mathrm{p}$. 475-508. In: B.A. Stewart and D.R. Nielson (eds.). Irrigation of agricultural crops. ASACSSA-SSSA Publ. Agron. Monogr. 30.

Lampinen, B.D., K.A. Shackel, S.M. Southwick, B. Olson, J.T. Yeager, and D. Goldhamer. 1995. Sensitivity of yield and fruit quality of French prune to water deprivation at different fruit growth stages. J. Amer. Soc. Hort. Sci. 120:139-147.

Layne, R.E.C. and C.S. Tan. 1984. Long-term influence of irrigation and tree density on growth, survival, and production of peach. J. Amer. Soc. Hort. Sci. 109:795-799.
Layne, R.E.C., C.S. Tan, and D.M. Hunter. 1996. Irrigation and fertilizer application methods affect performance of high-density peach orchards. HortScience 31:370-375.

Li, S-H., J-G. Huguet, P.G. Schoch, and P. Orlando. 1989. Response of peach tree growth and cropping to soil water deficit at various phenological stages of fruit development. J. Hort. Sci. 64:541-552.

Mandre, O., M. Rieger, S.C. Myers, R. Seversen, and J.L. Regnard. 1995. Interaction of root confinement and fruiting in peach. J. Amer. Soc. Hort. Sci. 120:228-234.

Marsal, J., G. Lopez, J. Girona, B. Basile, and T.M. DeJong. 2005. Heterogeneity in fruit distribution and stem water potential variation in peach trees under different irrigation conditions. J. Hort. Sci. Biotechnol. 80:82-86.

McCutchan, H. and K.A. Shackel. 1992. Stem-water potential as a sensitive indicator of water stress in prune trees (Prunus domestica L. cv. French). J. Amer. Soc. Hort. Sci.117:607-611.

Middleton, J.E., E.L. Proebsting, and S. Roberts. 1979. Apple orchard irrigation by trickle and sprinkler. Trans. Amer. Soc. Agr. Eng. 


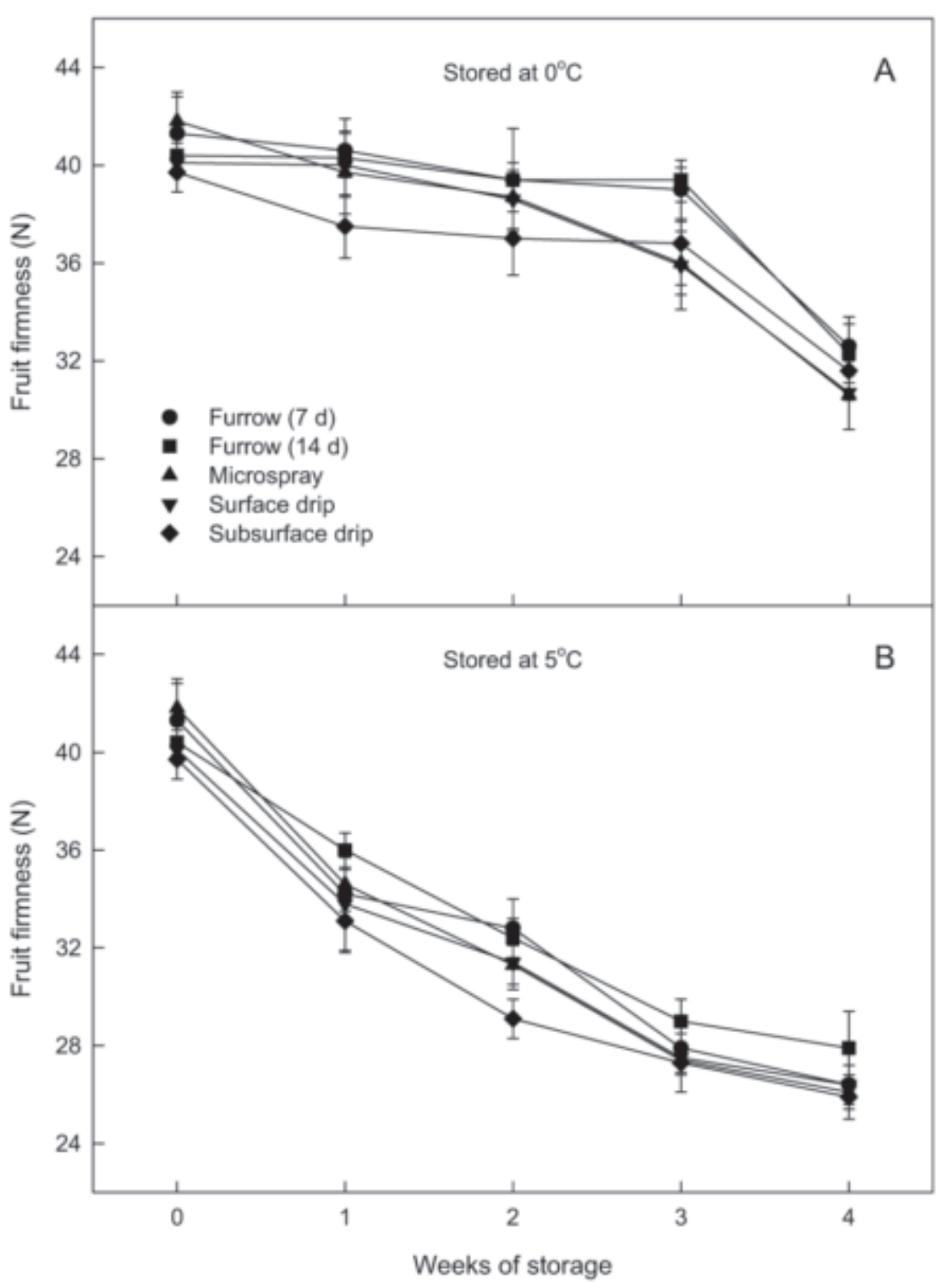

Fig. 3. Weekly changes in fruit firmness of 'Crimson Lady' peaches stored at $(\mathbf{A}) 0^{\circ} \mathrm{C}$ or $(\mathbf{B}) 5^{\circ} \mathrm{C}$. Peaches were harvested on 28 May 2002 (second picking) from trees irrigated by furrow (every 7 or 14 d), microspray, surface drip, or subsurface drip. Values are the mean of six replications and error bars represent 1 SE.
22:582-584.

Mitchell, P.D. and D.J. Chalmers. 1983. A comparison of microjet and point emitter (trickle) irrigation in the establishment of a high-density peach orchard. HortScience 18:472-474.

Naor, A. 2001. Irrigation and crop load influence fruit size and water relations in field-grown 'Spadona' pear. J. Amer. Soc. Hort. Sci. 126:252-255.

Naor, A., I. Klein, and I. Doron. 1995. Stem water potential and apple size. J. Amer. Soc. Hort. Sci. 120:577-582.

Naor, A., I. Klein, H. Hupert, Y. Grinblat, M. Peres, and A. Kaufman. 1999. Water stress and crop level interactions in relation to nectarine yield, fruit size distribution, and water potentials. J. Amer. Soc. Hort. Sci. 124:189-193.

Naor, A., H. Hupert, Y. Greenblat, M. Peres, A. Kaufman, and I. Klein. 2001. The response of nectarine fruit size and midday stem water potential to irrigation level in stage III and crop load. J. Amer. Soc. Hort. Sci. 126:140-143.

Pregitzer, K.S., R.L. Hendrick, and R. Fogel. 1993. The demography of fine roots in response to patches of water and nitrogen. New Phytol. 125:575-580.

Radin, J.W., J.R. Mauney, and P.C. Kerridge. 1989. Water uptake by cotton roots during fruit filling in relation to irrigation frequency. Crop Sci. 29:1000-1005.

Reeder, B.D., J.S. Newman, and J.W. Worthington. 1979. Effect of trickle irrigation on peach trees. HortScience 14:36-37.

Schwankl, L.J., J.P. Edstrom, J.W. Hopmans, L. Andreu, and K.S. Koumanov. 1999. Microsprinklers wet larger soil volume; boost almond yield, tree growth. Calif. Agr. (March-April):39-43.

Swietlik, D. 1992. Yield, growth, and mineral nutrition of young 'Ray Ruby' grapefruit trees under trickle or flood irrigation and various nitrogen rates. J. Amer. Soc. Hort. Sci. 117:22-27.

Tan, C.S. and B.R. Buttery. 1982. The effect of soil moisture stress to various fractions of the root system on transpiration, photosynthesis, and internal water relations of peach seedlings. J. Amer. Soc. Hort. Sci. 107:845-849.

Williamson, J.G., D.C. Coston, and J.A. Cornell. 1992. Root restriction affects shoot development of peach in a high-density orchard. J. Amer. Soc. Hort. Sci. 117:362-367.

Zekri, M. and L.R. Parsons. 1988. Water relations of grapefruit trees in response to drip, microsprinkler, and overhead sprinkler irrigation. J. Amer. Soc. Hort. Sci. 113:819-823. 